\title{
A Successful Infusion Process for Enabling Lunar Exploration Technologies
}

Ann P. Over, Mark K. Klem, and Susan M. Motil

Glenn Research Center, Cleveland, Ohio 


\section{NASA STI Program . . . in Profile}

Since its founding, NASA has been dedicated to the advancement of aeronautics and space science. The NASA Scientific and Technical Information (STI) program plays a key part in helping NASA maintain this important role.

The NASA STI Program operates under the auspices of the Agency Chief Information Officer. It collects, organizes, provides for archiving, and disseminates NASA's STI. The NASA STI program provides access to the NASA Aeronautics and Space Database and its public interface, the NASA Technical Reports Server, thus providing one of the largest collections of aeronautical and space science STI in the world. Results are published in both non-NASA channels and by NASA in the NASA STI Report Series, which includes the following report types:

- TECHNICAL PUBLICATION. Reports of completed research or a major significant phase of research that present the results of NASA programs and include extensive data or theoretical analysis. Includes compilations of significant scientific and technical data and information deemed to be of continuing reference value. NASA counterpart of peer-reviewed formal professional papers but has less stringent limitations on manuscript length and extent of graphic presentations.

- TECHNICAL MEMORANDUM. Scientific and technical findings that are preliminary or of specialized interest, e.g., quick release reports, working papers, and bibliographies that contain minimal annotation. Does not contain extensive analysis.

- CONTRACTOR REPORT. Scientific and technical findings by NASA-sponsored contractors and grantees.

- CONFERENCE PUBLICATION. Collected papers from scientific and technical conferences, symposia, seminars, or other meetings sponsored or cosponsored by NASA.

- SPECIAL PUBLICATION. Scientific, technical, or historical information from NASA programs, projects, and missions, often concerned with subjects having substantial public interest.

- TECHNICAL TRANSLATION. Englishlanguage translations of foreign scientific and technical material pertinent to NASA's mission.

Specialized services also include creating custom thesauri, building customized databases, organizing and publishing research results.

For more information about the NASA STI program, see the following:

- Access the NASA STI program home page at http://www.sti.nasa.gov

- E-mail your question via the Internet to help@ sti.nasa.gov

- Fax your question to the NASA STI Help Desk at 301-621-0134

- Telephone the NASA STI Help Desk at 301-621-0390

- Write to: NASA Center for AeroSpace Information (CASI) 7115 Standard Drive Hanover, MD 21076-1320 


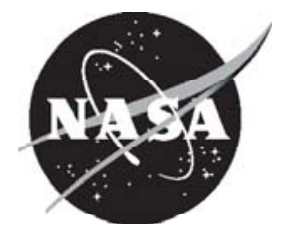

\section{A Successful Infusion Process for Enabling Lunar Exploration Technologies}

Ann P. Over, Mark K. Klem, and Susan M. Motil

Glenn Research Center, Cleveland, Ohio

Prepared for the

Space 2007

sponsored by the American Institute of Aeronautics and Astronautics

Long Beach, California, September 18-20, 2007

National Aeronautics and

Space Administration

Glenn Research Center

Cleveland, Ohio 44135 


\section{Acknowledgments}

The authors would like to thank the Exploration Technology and Development and Constellation Program Offices for their continued support in funding the work to enable NASA's Vision for Space Exploration, the Lunar Architecture Team for their vision of lunar sorties and outposts, and the Lunar Lander Project Office for their cooperative spirit to establish the technology portfolio to meet the lander needs.

Level of Review: This material has been technically reviewed by technical management.

Available from

NASA Center for Aerospace Information 7115 Standard Drive

Hanover, MD 21076-1320
National Technical Information Service 5285 Port Royal Road Springfield, VA 22161

Available electronically at http://gltrs.grc.nasa.gov 


\title{
A Successful Infusion Process for Enabling Lunar Exploration Technologies
}

\author{
Ann P. Over, Mark K. Klem, and Susan M. Motil \\ National Aeronautics and Space Administration \\ Glenn Research Center \\ Cleveland, Ohio 44135
}

\begin{abstract}
The NASA Vision for Space Exploration begins with a more reliable flight capability to the International Space Station and ends with sending humans to Mars. An important "stepping stone" on the path to Mars encompasses human missions to the Moon. There is little doubt throughout the stakeholder community that new technologies will be required to enable this Vision. However, there are many factors that influence the ability to successfully infuse any technology including the technical risk, requirement and development schedule maturity, and, funds available. This paper focuses on effective infusion processes that have been used recently for the technologies in development for the lunar exploration flight program, Constellation. Recent successes with Constellation customers are highlighted for the Exploration Technology Development Program (ETDP) Projects managed by NASA Glenn Research Center (GRC). Following an overview of the technical context of both the flight program and the technology capability mapping, the process is described for how to effectively build an integrated technology infusion plan. The process starts with a sound risk development plan and is completed with an integrated project plan, including content, schedule and cost. In reality, the available resources for this development are going to change over time, necessitating some level of iteration in the planning. However, the driving process is based on the initial risk assessment, which changes only when the overall architecture changes, enabling some level of stability in the process.
\end{abstract}

\section{Nomenclature}

$\begin{array}{ll}\text { CaLV } & \text { Cargo Launch Vehicle } \\ \text { CEV } & \text { Orion Crew Exploration Vehicle } \\ \text { CFM } & \text { Cryogenic Fluid Management } \\ \text { CLV } & \text { Ares Crew Launch Vehicle } \\ \text { CSA } & \text { Customer Supplier Agreement } \\ \text { CxP } & \text { Constellation Program } \\ \text { EDS } & \text { Earth Departure Stage } \\ \text { ESAS } & \text { Exploration Systems Architecture Study } \\ \text { ETDP } & \text { Exploration Technology Development Program } \\ \text { EVA } & \text { Extra Vehicular Activity } \\ \text { GRC } & \text { NASA Glenn Research Center } \\ \text { ISRU } & \text { In-Situ Resource Utilization } \\ \text { LAT } & \text { Lunar Architecture Team } \\ \text { PCAD } & \text { Propulsion and Cryogenics Advanced Development } \\ \text { PDR } & \text { Preliminary Design Review } \\ \text { RCS } & \text { Reaction Control System } \\ \text { SE\&I } & \text { Systems Engineering and Integration } \\ \text { SOA } & \text { State of the Art } \\ \text { SRR } & \text { Systems Requirements Review } \\ \text { TBR } & \text { To Be Resolved } \\ \text { TRL } & \text { Technology Readiness Level } \\ \text { VSE } & \text { Vision for Space Exploration } \\ & \end{array}$




\section{Introduction}

The NASA Vision for Space Exploration (VSE) includes human space flight missions to the International Space Station, the Moon, and Mars. To accomplish the VSE, several iterations of architecture studies and concept development have been completed. The Exploration Systems Architecture Study (ESAS) completed and published in December of 2005 included a detailed transportation architecture for all three missions, which was subsequently refined. The Lunar Architecture Team (LAT) study, published in December of 2006, focused on defining the surface architecture and detailed drivers for lunar surface operations. At the writing of this paper, a follow-on study, LAT-2 is nearing completion to refine the architecture further. Each of these mission concepts identified technology that was required to "enable" the mission concepts, as well as technology that was highly desired to "enhance" the mission. Technology solutions enable missions by buying down the risk on mission performance, life-cycle costs, and/or safety and reliability. In an ideal situation, NASA would fund all technologies that had promise of payback for later missions. However, fiscal realities are such that only the highest priority subset of the technologies identified can be funded and this decision process is a significant challenge. Perhaps more importantly, there are many factors that influence the ability to successfully infuse any technology including the technical risk, requirement and development schedule maturity, and, funds available. This paper focuses on the successful infusion processes that have been used recently for the technologies in development for the lunar exploration flight program, Constellation. One technology project, Propulsion and Cryogenics Advanced Development (PCAD), has implemented an effective technology infusion process with the Lunar Lander flight project. A similar process was recently applied across the power technology needs starting with the Energy Storage Project. With the help of ETDPO, other successful technology projects, and the Constellation customers, an effective technology infusion process is now in implementation across the program. With the VSE, there is an unprecedented opportunity to make this technology infusion a success because of the strong "technology pull" to enable the missions.

\section{Vision for Space Exploration Architectures}

The Exploration Systems Architecture Study (ESAS) completed in December 2005 included a lunar transportation architecture as shown in figure 1.

This architecture was updated and modified through follow-on studies including the Lunar Lander internal study concepts and the Lunar Architecture Team. For example, the Lander key design drivers were to minimize mass of the descent and ascent stages to allow the maximum payload possible, and, to simplify the interfaces.

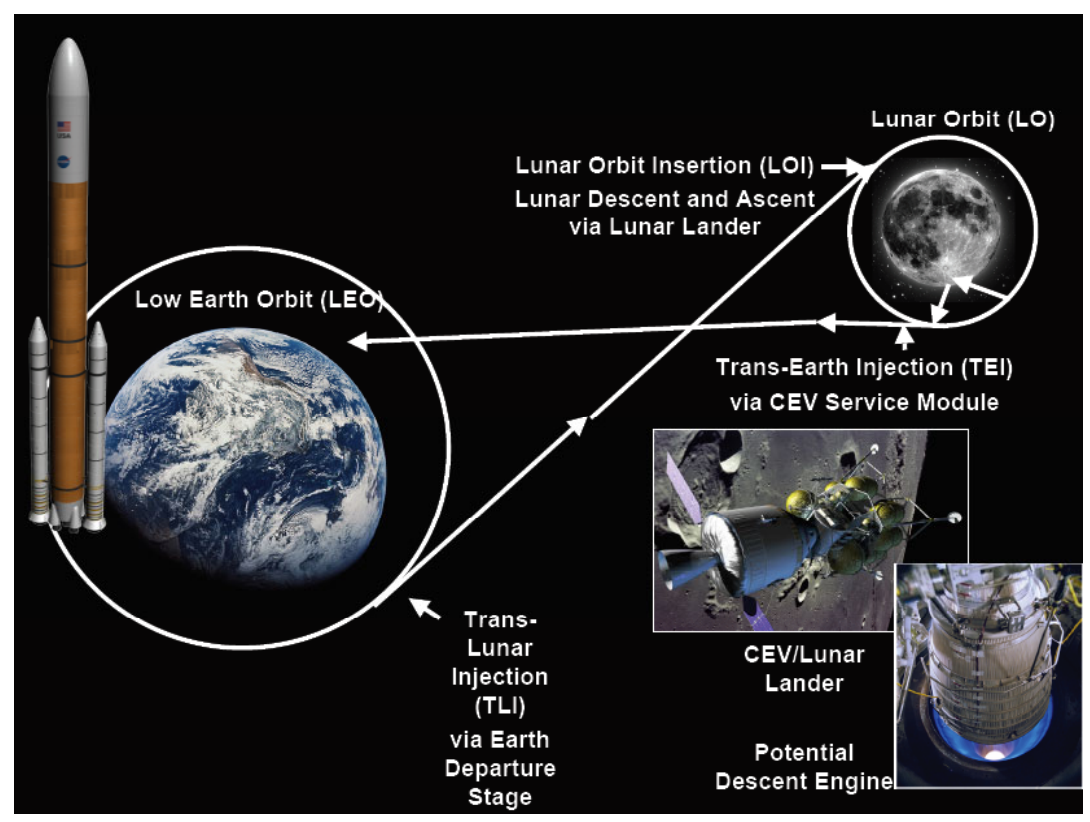

Figure 1.-Exploration Transportation Architecture 


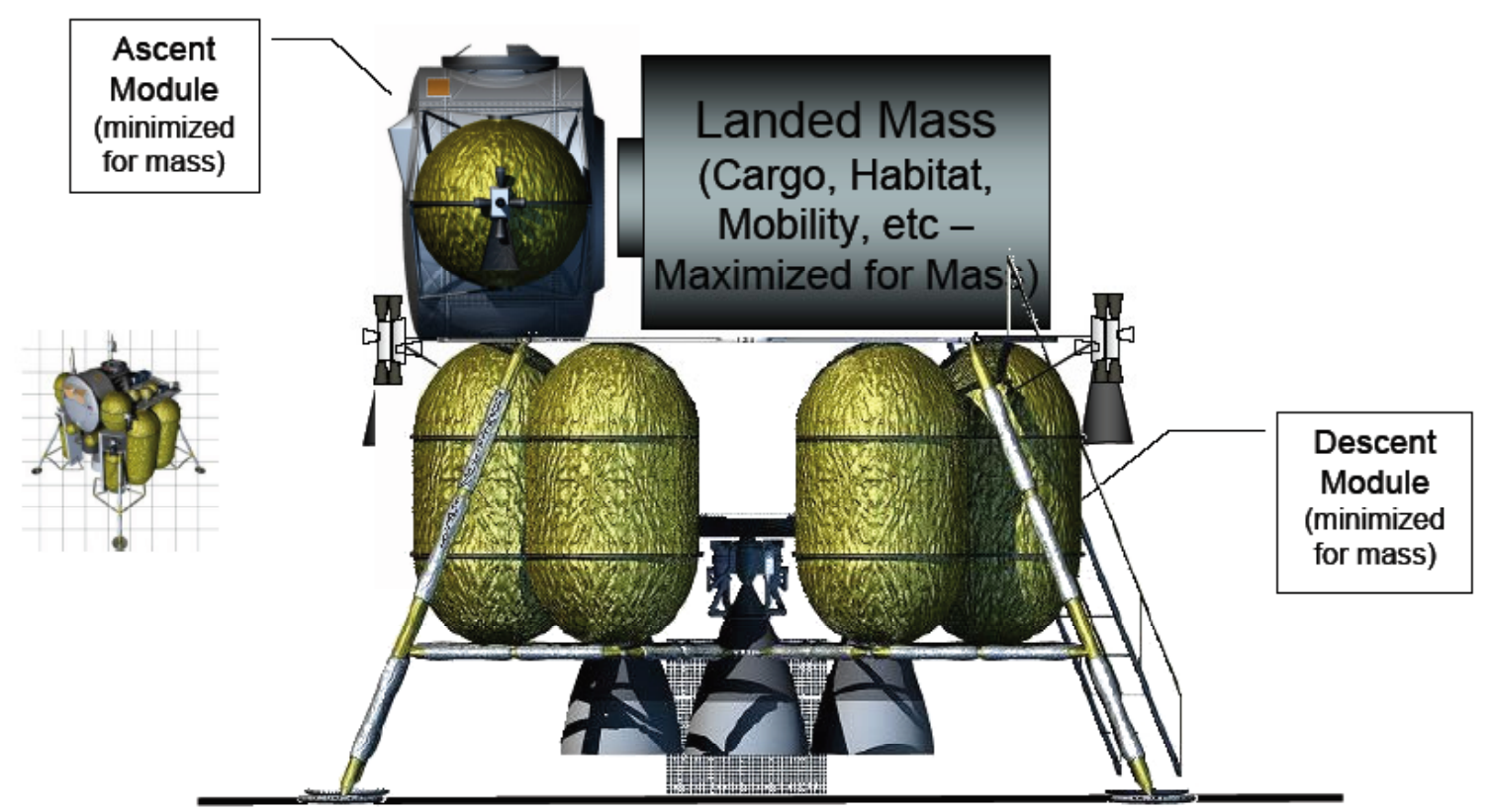

Figure 2.-Notional LAT Lander Concept

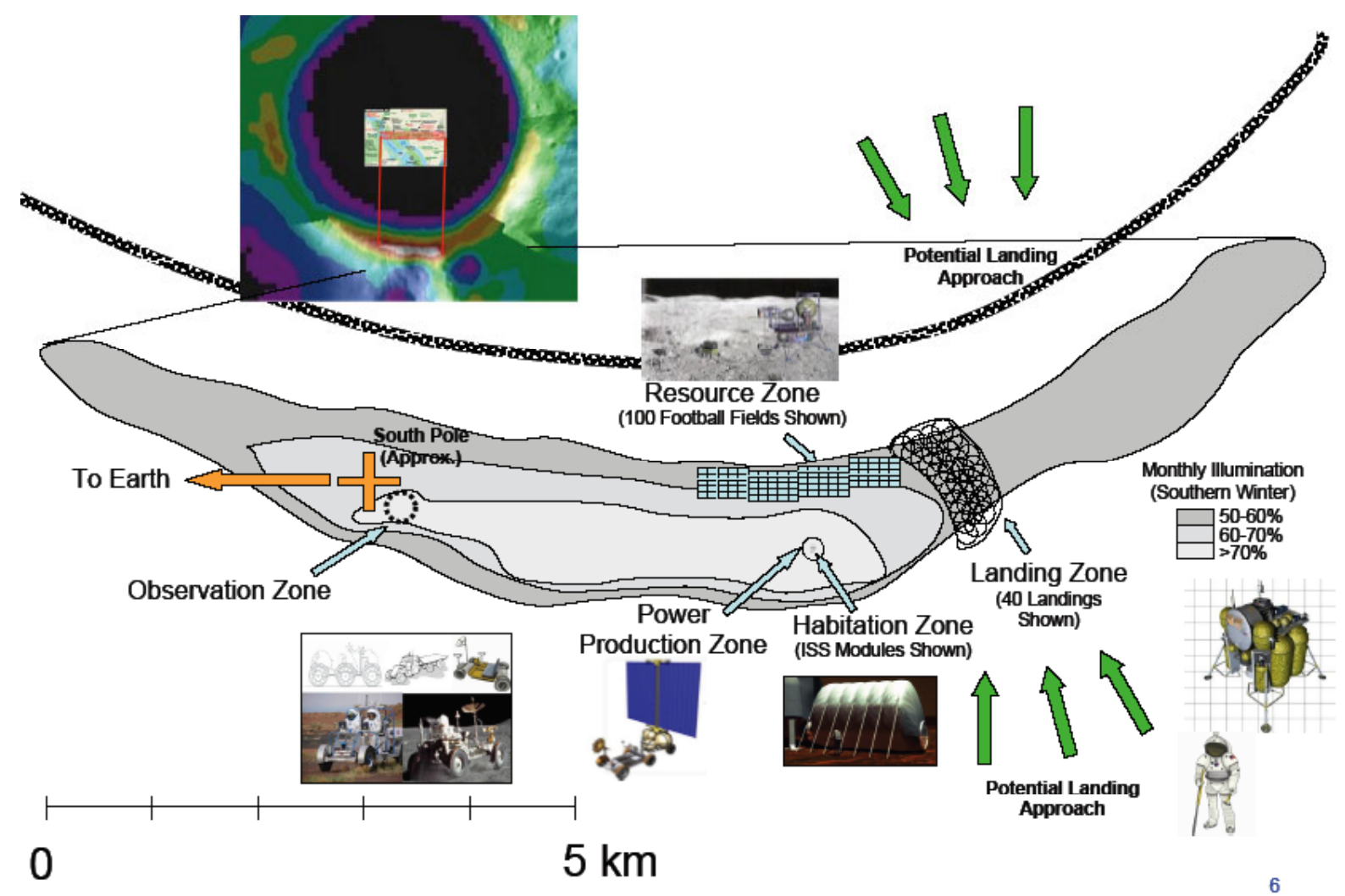

Figure 3.-Notional LAT Surface Architecture Concept

In addition to the Lunar Lander, based on the objectives defined for the lunar missions, a surface architecture was defined including surface power, surface communications, habitats, rovers for humans and science, and in-situ resource utilization. A notional architecture is shown in figure 3. 


\section{Architecture Driven Technology Needs}

The architecture studies described above each precipitated a time-phased list of technology needs required to achieve the architecture concept of operations. The ETDP was formulated to address these technology needs. The current program consists of 21 technology projects, most containing multiple technologies within each project, each addressing one or more elements of the future flight systems as depicted in table 1.

TABLE 1.-TECHNOLOGY MAPPING TO CONSTELLATION FLIGHT ELEMENTS

\begin{tabular}{|c|c|c|c|c|c|c|c|c|c|c|c|c|c|c|}
\hline \multirow[b]{2}{*}{ Discipline } & \multirow[b]{2}{*}{$\begin{array}{c}\text { Technology Project } / \\
\text { Constellation Flight Element }\end{array}$} & \multirow[b]{2}{*}{$\begin{array}{l}\text { Orion } \\
\text { (CEV) }\end{array}$} & \multicolumn{3}{|c|}{ Launch Vehicle } & \multirow[b]{2}{*}{$\begin{array}{l}\text { Lunar } \\
\text { Lander }\end{array}$} & \multirow[b]{2}{*}{ EVA } & \multicolumn{6}{|c|}{ Lunar Surface Systems } & \multirow[b]{2}{*}{$\begin{array}{l}\text { Ground } \\
\text { or Flight } \\
\text { Ops/ SE\&I }\end{array}$} \\
\hline & & & $\begin{array}{l}\text { ARES-I } \\
\text { (CLV) }\end{array}$ & $\begin{array}{c}\text { ARES-V } \\
\text { (CaLV) }\end{array}$ & EDS & & & Power & Habitat & Mobility & ISRU & Comm & $\begin{array}{l}\text { Cross- } \\
\text { cutting/ } \\
\text { Outpost }\end{array}$ & \\
\hline Mechanical & $\begin{array}{c}\text { Structures, Materials, \& } \\
\text { Mechanisms }\end{array}$ & $\bullet$ & - & & $\bullet$ & $\bullet$ & & & - & $\bullet$ & $\bullet$ & & & \\
\hline \multirow{2}{*}{$\begin{array}{l}\text { Protection } \\
\text { Systems }\end{array}$} & Thermal Protection Systems & $\bullet$ & & & & & & & & & & & & \\
\hline & Dust Management & & & & & $\bullet$ & $\bullet$ & $\bullet$ & $\bullet$ & $\bullet$ & $\bullet$ & $\bullet$ & $\bullet$ & \\
\hline \multirow{2}{*}{ Propulsion } & $\begin{array}{c}\text { Propulsion and Cryo } \\
\text { Advanced Development }\end{array}$ & $\bullet$ & & & & $\bullet$ & & & & & & & & \\
\hline & Cryogenic Fluid Management & $\bullet$ & & & $\bullet$ & $\bullet$ & & & & & $\bullet$ & & $\bullet$ & $\bullet$ \\
\hline \multirow{2}{*}{ Power } & $\begin{array}{c}\text { Energy Storage (Batteries \& } \\
\text { Fuel Cells) }\end{array}$ & & & $\bullet$ & & $\bullet$ & $\bullet$ & $\bullet$ & & $\bullet$ & $\bullet$ & $\bullet$ & $\bullet$ & \\
\hline & $\begin{array}{c}\text { Advanced Fission Surface } \\
\text { Power }\end{array}$ & & & & & & & $\bullet$ & & & & & $\bullet$ & \\
\hline Thermal & Thermal Controls & $\bullet$ & & & & $\bullet$ & $\bullet$ & & $\bullet$ & $\bullet$ & $\bullet$ & & $\bullet$ & \\
\hline \multirow{6}{*}{$\begin{array}{l}\text { Avionics \& } \\
\text { Software }\end{array}$} & $\begin{array}{c}\text { High Performance \& Rad Hard } \\
\text { Electronics }\end{array}$ & $\bullet$ & & & & $\bullet$ & $\bullet$ & & & & & $\bullet$ & $\bullet$ & \\
\hline & $\begin{array}{c}\text { Integrated System Health } \\
\text { Management }\end{array}$ & & $\bullet$ & & & & & & & & & & & \\
\hline & Automation for Operations & & & & & & & & & & & & & $\bullet$ \\
\hline & Intelligent Software Design & $\bullet$ & & & & & & & & & & & & $\bullet$ \\
\hline & $\begin{array}{c}\text { Autonomous Precision } \\
\text { Landing }\end{array}$ & & & & & $\bullet$ & & & & & & & & \\
\hline & $\begin{array}{c}\text { Automated Rendezvous \& } \\
\text { Docking Sensor }\end{array}$ & - & & & & & & & & & & & & \\
\hline \multirow{3}{*}{$\begin{array}{l}\text { Environmental } \\
\text { Control \& Life } \\
\text { Support }\end{array}$} & Exploration Life Support & $\bullet$ & & & & & & & - & & & & $\bullet$ & \\
\hline & $\begin{array}{c}\begin{array}{c}\text { Environmental Monitoring and } \\
\text { Control }\end{array} \\
\end{array}$ & • & & & & • & & & $\bullet$ & & & & $\bullet$ & \\
\hline & \begin{tabular}{|c} 
Fire Prevention, Detection \& \\
Supression
\end{tabular} & $\bullet$ & & & & $\bullet$ & & & - & & & & & $\bullet$ \\
\hline Crew Support & Extra Vehicular Activity (EVA) & & & & & & $\bullet$ & & & & & & & \\
\hline ISRU & In-Situ Resource Utilization & & & & & & & & & & $\bullet$ & & $\bullet$ & \\
\hline \multirow{2}{*}{$\begin{array}{c}\text { Robotics, } \\
\text { Operations and } \\
\text { Supportability }\end{array}$} & Supportability & & & & & & & & & & & & $\bullet$ & $\bullet$ \\
\hline & Human-Robotic Systems & & & & & & & & & $\bullet$ & & & $\bullet$ & \\
\hline
\end{tabular}

\section{Technology Prioritization}

The technology areas in table 1 represent technology needs identified by the general architecture assessments such as ESAS and LAT. This identification as a promising technology in architecture assessments is a necessary but not sufficient condition to remain funded. The Constellation Program (CxP), who manages the development of the Exploration flight elements, in concurrence with NASA Headquarters and the ETDP, has implemented a Technology Prioritization Process (TPP) ${ }^{1}$ to assess and prioritize the technology needs across the program. The CxP process includes rigorous systems engineering assessments to identify and prioritize the technology capabilities required to meet the design, development, and test of mission systems, going beyond the initial architecture assessments. These capabilities are identified by mission phase (Initial/ISS, Lunar, or Mars) and by "enabling" or "enhancing." In this context, the mission cannot be completed without the enabling technology. However, the enhancing technologies allow missions with better performance and/or lower risk and life cycle costs. The net result is an integrated technology priority list identifying the "pull technologies." In the case where flight system requirements are not well defined, the technology program works with the architecture concept leads to define core

${ }^{1}$ Constellation Program Technology Insertion Strategy Document, CxP 70079 
technologies that cross most architecture solutions, working to supplement the TPP process. For example, although the exact mobility needs are not known for the surface we know that low power, lunar environment tolerant (e.g., dust, vacuum, temperature) mobility subsystems are required to be developed.

\section{Technology Infusion Process}

At the macro scale, a technology may have been identified as critical and selected for funding based on the program priority list. Although a technology development has sufficient funding and some level of success with development, it may not be used in the target flight system, or "infused." There are many factors that influence the ability to successfully infuse any technology including the technical risk, requirement and development schedule maturity, and funds available. An effective infusion process has been demonstrated by the ETDP PCAD Project, managed at GRC. The PCAD project content includes "green propulsion" (non-toxic) main and reaction control system (RCS) propulsion, currently including hydrogen and methane fuels. PCAD also includes Cryogenic Fluid Management (CFM) content including storage, distribution, and low gravity management of cryogenic fluids for vehicles and surface systems. PCAD's process started with a sound risk development plan and was completed with an integrated project plan, including content, schedule and cost. The following are details of the infusion process that recently worked well between the PCAD and the Lunar Lander Projects.

\section{A. Baseline Requirements and Definitions}

To start the infusion process, the needs, goals, and objectives of the flight program need to be stated in a set of requirements. For PCAD, although the Lander did not have baselined requirements they were able to confirm the majority of the requirements to guide the technology development. An example of those requirements is for the Lander liquid oxygen (LOx), liquid methane ascent main engine as shown in table 2.

TABLE 2.-EXAMPLE OF LANDER LOx-METHANE ASCENT MAIN ENGINE PRELIMINARY REQUIREMENTS

\begin{tabular}{|c|c|c|}
\hline Performance & Life & Propellant inlet conditions \\
\hline Total thrust: 3,500 to $7,500 \mathrm{lbf}$ (TBR) & 6 starts (TBR) & Pressure: 325 psia \\
\hline Isp: $355 \mathrm{sec}$ minimum End of Life & 9 months in space (TBR) & Temperature: $185^{\circ} \mathrm{R}$ \\
\hline Start time: $0.5 \mathrm{sec}(\max )$ & Impulse (includes 1.5x margin) & \\
\hline Vacuum start & $\begin{array}{l}\text { Continuous:4,500K lbf*sec } \\
\text { (650 sec @ 7.5K) (TBR) }\end{array}$ & $\begin{array}{l}\text { LOx temperature: } 163 \text { to } 224^{\circ} \mathrm{R} \text { with a } \\
\text { goal down to } 145^{\circ} \mathrm{R}\end{array}$ \\
\hline & $\begin{array}{l}\text { Continuous:4,500K lbf* sec } \\
\text { (1425 sec @ 7.5K) (TBR) }\end{array}$ & $\begin{array}{l}\mathrm{LCH}_{4} \text { temperature: } 170 \text { to } 224{ }^{\circ} \mathrm{R} \text { with a } \\
\text { goal up to } 264{ }^{\circ} \mathrm{R}\end{array}$ \\
\hline & Sun and deep space viewing & Startup vapor slug: 100 in. $^{3}$ \\
\hline
\end{tabular}

In addition to requirements, there must be an understanding and definition of what Technology Readiness Level $(\mathrm{TRL})^{2}$ means for a given technology. For example, in general Exploration has a goal to develop technologies to a TRL level of 6 before they are delivered to the flight program for engineering development. For propulsion and CFM, PCAD spent significant time to define what TRL meant for their disciplines. In general, most technologies have a range of infusion points that follow the maturity of the flight design. For example, at SRR the technology development may not be complete; however, enough risk mitigation has been accomplished to adequately address the design maturity and risk.

\section{B. Technology Risk Assessment}

The PCAD Team conducted a risk workshop to identify the risks to be able to meet the Lunar Lander and CEV propulsion system requirements. A rigorous risk identification process was used to enable succinct statements of the risk, a relative ranking, mitigation strategies, and ultimately customer ownership. These risks serve to identify the technology gaps compared to State of the Art (SOA). The workshop provided raw data that needed to be consolidated for each area. This process resulted in a prioritized set of risks for the Lander propulsion system as shown in table 3. The color-coding for the risk corresponds to the scoring of likelihood (1-5) multiplied by consequence (1-5). Reds are 15-25; yellows 8-12 and greens are $<8$. The PCAD Risk abbreviations are "G" for green propulsion (e.g., methane fuel), "C" for CFM and, "D" for deep-throttling main engines. For example, the first

${ }^{2}$ TRL levels as defined in the NASA White Paper “Technology Readiness Levels” by John C. Mankins, April 1995. 
risk in the table, G15 was $15^{\text {th }}$ risk at the workshop for green propulsion and it covered ignition reliability for liquid oxygen-liquid methane combination. Customer interaction at the actual workshop was limited, hence follow-up meetings were held with the customer to review and refine the risks and associated mitigation strategies, and to effectively transfer ownership of the risks.

\begin{tabular}{|c|c|c|}
\hline Lunar Lander Risk & Risk Statement & Corresponding PCAD Green Propulsion Risk \\
\hline $\begin{array}{l}\text { RCS \& Ascent Engine } \\
\text { Ignition }\end{array}$ & $\begin{array}{l}\text { Given that LOX/Methane are non-hypergolic propellants, an } \\
\text { ignition system is required; Because no space qualified } \\
\text { hardware currently exists for LOX/Methane there are risks that } \\
\text { the required ignition systems will not be at a TRL of } 6 \text { prior to } \\
\text { full-scale development. }\end{array}$ & \begin{tabular}{|l|} 
G15 - Ignition Reliability \\
G31 - Lack of Space Qualified Exciters \\
G30 - Lack of Qualified Spark Plug for High Cycle Applications \\
C088 - Propellant Acquisition \\
G35 - RCS Igniter Integration with Main Stage
\end{tabular} \\
\hline $\begin{array}{l}\text { LOX/Methane Propulsion } \\
\text { Technology Maturity }\end{array}$ & $\begin{array}{l}\text { Given that flight-qualified, human-rated LOX/Methane } \\
\text { propulsions systems do not currently exist, there is a limited } \\
\text { amount of data at both the component and system level to } \\
\text { guide mission planning and provide confidence the systems will } \\
\text { meet performance targets. }\end{array}$ & $\begin{array}{l}\text { G02 - Integrated System Test Requirement } \\
\text { C051 - CFM System Level Integration } \\
\text { G26 - Lack of Performance Data to Benchmark Analytical Models } \\
\text { G36 - Performance Loss Due to Propellant Quality } \\
\text { G09 - Material Limits at High Temperature Operation } \\
\text { G29 - Propellant Delivery Timing \& Valve Operations } \\
\text { G19 - Thermal Cycle Limits of Thrust Chambers } \\
\text { G17 - Combustion Stability Characteristics } \\
\text { G06 - Engine Health Monitoring }\end{array}$ \\
\hline $\begin{array}{l}\text { Unknown Ascent/RCS } \\
\text { Propulsion System } \\
\text { Requirements }\end{array}$ & $\begin{array}{l}\text { Given that advanced development of LOX/Methane propulsion } \\
\text { technology is proceeding prior to establishment of LSAM ascent } \\
\text { and RCS requirements; there is a risk that the advances made } \\
\text { through PCAD will not satisfy these future requirements. } \\
\text { Alternatively, if advanced development is to satisfy a very wide } \\
\text { range of potential requirements there is a risk that PCAD } \\
\text { resources \& schedule are inadequate. }\end{array}$ & \begin{tabular}{|l} 
G27 - Variable Requirements \\
G25 - Start Transient Requirements \\
G37 - Heat soakback requirements \\
G50 - Thermal Exposure Variations \\
G22 - Propellant Specification \\
\end{tabular} \\
\hline $\begin{array}{l}\text { LOX/Methane Test Facility } \\
\text { Suitability \& Availability }\end{array}$ & $\begin{array}{l}\text { Given that there are limited contractor and government test } \\
\text { facilities currently supporting a range of Cx propulsion system } \\
\text { development activities; there is a risk that necessary advanced } \\
\text { development tests cannot be accomplished when needed. }\end{array}$ & G4 - L \\
\hline $\begin{array}{l}\text { LOX/ H2 Ascent Engine Fast } \\
\text { Start }\end{array}$ & $\begin{array}{l}\text { Given that a pump fed LOX/ H2 engine is being considered for } \\
\text { LSAM Ascent and the engine has a requirement to be able to } \\
\text { perform during certain abort scenarios, there is a possibility } \\
\text { that it might not meet the engine quick/fast start requirements } \\
\text { for the abort. }\end{array}$ & D95 - LOX/ H2 Ascent Engine Fast Start \\
\hline $\begin{array}{l}\text { Descent Engine } \\
\text { Performance }\end{array}$ & $\begin{array}{l}\text { Given the propulsion needs for high performance, reliable lunar } \\
\text { descent, there is a risk that this capability cannot be met using } \\
\text { an engine design within the current technology base (RL-10 } \\
\text { derivative). }\end{array}$ & \begin{tabular}{|l} 
D91 - Inconsistent Assumptions Between Performance, Cost \& \\
D101 - Deep Throttle Enqine Overall Performance \\
D104 - Deep Throttle Engine Human Rating \\
D-97 - Deep Throttle Engine, Unclear Requirements \\
\end{tabular} \\
\hline Descent Deep Throttling & $\begin{array}{l}\text { Given that the lunar descent propulsion will need engines to } \\
\text { provide a wide range of thrust, there is a risk that throttling } \\
\text { requirements cannot be met. }\end{array}$ & \begin{tabular}{|l} 
D89 - Deep Throttle Engine Throttling \\
D94 - Deep Throttle Engine Specific Impulse \\
D102 - Deep Throttle Transient Response \\
D108 - DTE Expander Cycle Heat Transfer \\
D88 - DTE Terrain Avoidance Maneuvers \\
D107 - DTE Expander Cycle Heat Output \\
D90 - DTE Engine Restart After Cold Soak \\
D106 - DTE Chug Stability \\
D109 - DTE Chamber Durability \\
D93 - DTE Weight \\
D103 - DTE Burn Time and Restart
\end{tabular} \\
\hline $\begin{array}{l}\text { Descent Engine } \\
\text { Development Base }\end{array}$ & $\begin{array}{l}\text { Given that there is limited expertise within both NASA and } \\
\text { industry, successful on-schedule descent engine development is } \\
\text { at risk. }\end{array}$ & $\begin{array}{l}\text { D112 - Limited Number of Qualified Suppliers for Deep Throttle Engine } \\
\text { D113 - Limited In-House Technical Competency }\end{array}$ \\
\hline $\begin{array}{l}\text { Cryogenic Propellant } \\
\text { Quality }\end{array}$ & $\begin{array}{l}\text { Given the nature of a distributed cryogenic propulsion system, } \\
\text { there is a risk that enqine feed quality will be unacceptable. }\end{array}$ & \begin{tabular}{|l|} 
C053 - RCS Feed line \\
C088 - Propellant Acquisition
\end{tabular} \\
\hline $\begin{array}{l}\text { Active Cooling for Thermal } \\
\text { Control }\end{array}$ & $\begin{array}{l}\text { Given that long duration liquid hydrogen storage is required, } \\
\text { active thermal control may be required to mitiqate boil-off. }\end{array}$ & $\begin{array}{l}\text { C090 - Long Term In-Space Cryogenic Propellant Storage } \\
\text { C065 - Active Cooling for Thermal Control }\end{array}$ \\
\hline $\begin{array}{l}\text { Cryogenic Fluid } \\
\text { Management Technology } \\
\text { Maturity }\end{array}$ & $\begin{array}{l}\text { Given that flight-qualified, human-rated long duration, on-orbit } \\
\text { cryogenic fluid management systems do not currently exist, } \\
\text { there are advanced development tasks at both the component } \\
\text { and system level that have not yet been completed. }\end{array}$ & \begin{tabular}{|l|} 
C090 - Long Term In-Space Cryogenic Propellant Storage \\
C091a - COPV for Cryogenic Propellants \\
C091b - COPV for High Pressure Helium \\
C092 - CFM Development Risk \\
C051 - CFM System Level Integration \\
C089 - Low Gravity Mass Gauge \\
C072 - Cryogenic Helium Regulator \\
\end{tabular} \\
\hline Lunar Dust Contamination & $\begin{array}{l}\text { Given that the LSAM will be exposed to lunar dust, there is a } \\
\text { risk that contamination could result in malfunctions }\end{array}$ & $\begin{array}{l}\text { D105 - LOX/ H2 Ascent Engine Contamination Due to Lunar Dust } \\
\text { C064 - Lunar Surface Thermal Control } \\
\text { G39 - Foreign Object Damage from Lunar Surface } \\
\end{array}$ \\
\hline
\end{tabular}

\section{Integrated Technology and Flight Schedules}

Based on the integrated risk matrix that was reviewed by the Lander, schedules for the technology development were developed to meet the flight project schedule. The risk mitigation items became tasks on a schedule supporting the Lander SRR and PDR, and some times post-PDR phases. Each task included an associated resource estimate. Several iterations were conducted to optimize the tasks (e.g., synergy was found by assuming the same reaction control system for the Ascent and Descent Stages). Throughout the process, all participants maintained a strict rigor to challenge task needs by inserting only mandatory tasks that met Lander schedule and critical risk mitigation 
needs. Based on the risk priorities and phasing of funding, the content within the planned budget and outside of the guideline was identified. Further iterations and scrubs of the task schedule were conducted to minimize the overguideline needs. By the end of this meticulous process, the Lander Project became the best advocate for the increased funding needs.

\section{Final Steps of Technology Infusion}

The final step in the process was the documentation of the PCAD technology deliverables to the Lander Project. This was accomplished with a Customer Supplier Agreement (CSA), ${ }^{3}$ including the technology development schedule of deliverables to meet the flight schedule needs, as shown in table 4. Over time, the Lander Project has continued to refine their requirements; however, the original PCAD risks were and still are applicable. The CSA with PCAD and the Lander Project, and the associated development schedule will remain a "living document" with periodic updates (at least once/year) to assure the alignment for technology infusion. Updates will also be required as the funding changes. The process outlined here, including a rigorous risk development process, enables a more stable development program that can adapt to changes.

TABLE 4.-PCAD AND LUNAR LANDER SCHEDULE FOR TECHNOLOGY DELIVERABLES

\begin{tabular}{|c|c|c|}
\hline Deliverables & $\begin{array}{c}\text { Expected } \\
\text { completion date }\end{array}$ & Description \\
\hline \multicolumn{3}{|c|}{ PCAD_Ascent/Descent RCS Design Deliverables } \\
\hline NGST RCS Contract & $4^{\text {th }}$ Qtr FY07 & Complete workhorse testing of RCS concept. Test Report \\
\hline Aerojet RCS Contract & $1^{\text {st }}$ Qtr FY08 & Deliver 4 Aerojet 100-Ibf RCS engines (Contract Option 3) \\
\hline $\begin{array}{l}\text { Igniter Duration Testing } \\
\text { (Duration and Wide Operating Range) }\end{array}$ & $1^{\text {st }}$ Qtr FY08 & Vacuum ignition pulse $(100,000+)$ duration testing \\
\hline High Area Ratio Testing & $3^{\text {rd }}$ Qtr FY08 & $\begin{array}{l}\text { Vacuum testing of a single engine to obtain performance data } \\
\text { and benchmark data to examine kinetics models in existing } \\
\text { analytical tools }\end{array}$ \\
\hline Spark Plug Durability & $4^{\text {th }}$ Qtr FY08 & $\begin{array}{l}\text { Heat transfer analysis and thermal stability analysis and test data } \\
\text { of current insulating materials in } \mathrm{LOx} / \mathrm{LCH}_{4} \text { environment }\end{array}$ \\
\hline $\begin{array}{l}\text { 100-lbf LOx/LCH }{ }_{4} \text { RCS Thruster Sea Level } \\
\text { Testing }\end{array}$ & $4^{\text {th }}$ Qtr FY08 & Sea level testing over a range of propellant inlet conditions \\
\hline 100-lbf LOx/LCH ${ }_{4}$ RCS Thruster APSTB & $1^{\text {st }}$ Qtr FY09 & $\begin{array}{l}\text { Vacuum testing of a } 3 \text { thruster reaction control box in a CEV } \\
\text { configuration }\end{array}$ \\
\hline Exciter Breadboard demonstration & $3^{\text {rd }}$ Qtr FY09 & $\begin{array}{l}\text { Breadboard testing of capacitive and/or inductive discharge } \\
\text { Ignition proof-of-concept (PoC) exciter designs }\end{array}$ \\
\hline $\begin{array}{l}\text { 100-lbf LOx/LCH }{ }_{4} \text { RCS Thruster Vacuum } \\
\text { Testing }\end{array}$ & $4^{\text {th }}$ Qtr FY09 & $\begin{array}{l}\text { Thermal vacuum testing over a range of propellant inlet } \\
\text { conditions }\end{array}$ \\
\hline LOx/LCH ${ }_{4}$ RCS Thruster APSTB & $4^{\text {th }}$ Qtr FY11 & $\begin{array}{l}\text { Testing of RCS engines and main engine simulator in lunar } \\
\text { lander APSTB configuration. }\end{array}$ \\
\hline \multicolumn{3}{|c|}{ PCAD—Ascent Main Engine Deliverables } \\
\hline KTE Workhorse Testing & $3^{\text {rd }}$ Qtr FY07 & $\begin{array}{l}\text { Complete sea level workhorse testing of } 7.5 \mathrm{~K}-\mathrm{lbf} \mathrm{LOx} / \mathrm{LCH}_{4} \text { main } \\
\text { engine concept. Test data report. }\end{array}$ \\
\hline KTE Contract & $4^{\text {th }}$ Qtr FY07 & $\begin{array}{l}\text { Complete contract base period with PDR for } 3.5 \mathrm{~K}-\mathrm{lbf} \mathrm{LOx} / \mathrm{LCH}_{4} \\
\text { prototype Ascent Main Engine. Workhorse test date and PDR } \\
\text { level engine design. }\end{array}$ \\
\hline ATK Contract & $4^{\text {th }}$ Qtr FY07 & $\begin{array}{l}\text { Complete contract base period with PDR for } 3.5 \mathrm{~K}-\mathrm{lbf} \mathrm{LOx} / \mathrm{LCH}_{4} \\
\text { prototype. Ascent Main Engine. Workhorse test date and PDR } \\
\text { level engine design. }\end{array}$ \\
\hline PWR Heated Tube SAA & $4^{\text {th }}$ Qtr FY07 & $\begin{array}{l}\text { Complete testing with super heated gaseous methane and } \\
\text { subcooled liquid methane - Test Results. }\end{array}$ \\
\hline Workhorse vacuum testing & $1^{\text {st }}$ Qtr FY09 & $\begin{array}{l}\text { Complete vacuum workhorse testing of } \mathrm{LOx} / \mathrm{LCH}_{4} \text { main engine } \\
\text { concept. Test data report }\end{array}$ \\
\hline ATK Workhorse Testing & $3^{\text {rd }}$ Qtr FY11 & $\begin{array}{l}\text { Complete sea level workhorse testing of } 7.5 \mathrm{~K}-\mathrm{lbf} \mathrm{LOx} / \mathrm{LCH}_{4} \text { main } \\
\text { engine concept. Test data report. }\end{array}$ \\
\hline Prototype engine demonstration & $1^{\text {st }}$ Qtr FY12 & $\begin{array}{l}\text { Complete design, development, fabrication and vacuum testing of } \\
\text { a lunar lander prototype ascent engine. }\end{array}$ \\
\hline
\end{tabular}

${ }^{3} \mathrm{CSA}$ is part of the Cx Technology Insertion Strategy document, CxP 70079 


\section{E. Other Technology Projects}

Other GRC ETDP Projects have enjoyed some success following the lead of PCAD. At the time of this writing, a Power Risk Workshop is planned for late August 2007 to identify the power technology risks for the Energy Storage and the Fission Surface Power Projects. This risk workshop and risk mitigation identification process will enable more rigorous integrated schedules and CSA's with the Lander, EVA, and various Lunar Surface Systems. The Dust Management Project is in formulation and is planning to utilize this process.

\section{Summary}

Historically it has been difficult to successfully infuse new technologies into flight systems. The Exploration Program, with the help of the Architecture Study teams, the ETDP and the Constellation Program, has developed a method to prioritize and manage the technology portfolio for the Agency. At a technology project level, this paper showed the details of an effective technology infusion process that was used by the ETDP PCAD Project, and is now in use by other technology projects. The driving process is based on rigorous risk assessments, which change only when the overall architecture changes, enabling some level of stability in the process to be able to accommodate the typical perturbations of most NASA programs, including budget fluctuations. 


\begin{tabular}{|c|c|c|c|c|c|}
\hline \multicolumn{5}{|c|}{ REPORT DOCUMENTATION PAGE } & $\begin{array}{l}\text { Form Approved } \\
\text { OMB No. 0704-0188 }\end{array}$ \\
\hline \multicolumn{6}{|c|}{$\begin{array}{l}\text { The public reporting burden for this collection of information is estimated to average } 1 \text { hour per response, including the time for reviewing instructions, searching existing data sources, gathering and maintaining the } \\
\text { data needed, and completing and reviewing the collection of information. Send comments regarding this burden estimate or any other aspect of this collection of information, including suggestions for reducing this } \\
\text { burden, to Department of Defense, Washington Headquarters Services, Directorate for Information Operations and Reports (0704-0188), } 1215 \text { Jefferson Davis Highway, Suite } 1204 \text {, Alrington, VA } 22202-402 \text {. } \\
\text { Respondents should be aware that notwithstanding any other provision of law, no person shall be subject to any penalty for failing to comply with a collection of information if it does not display a currently valid OMB } \\
\text { control number. } \\
\text { PLEASE DO NOT RETURN YOUR FORM TO THE ABOVE ADDRESS. }\end{array}$} \\
\hline \multicolumn{2}{|c|}{$\begin{array}{l}\text { 1. REPORT DATE (DD-MM-YYYY) } \\
01-01-2008\end{array}$} & \multicolumn{3}{|c|}{$\begin{array}{l}\text { 2. REPORT TYPE } \\
\text { Technical Memorandum }\end{array}$} & 3. DATES COVERED (From - To) \\
\hline \multirow{3}{*}{\multicolumn{5}{|c|}{$\begin{array}{l}\text { 4. TITLE AND SUBTITLE } \\
\text { A Successful Infusion Process for Enabling Lunar Exploration Technologies }\end{array}$}} & 5a. CONTRACT NUMBER \\
\hline & & & & & 5b. GRANT NUMBER \\
\hline & & & & & 5c. PROGRAM ELEMENT NUMBER \\
\hline \multirow{3}{*}{\multicolumn{5}{|c|}{$\begin{array}{l}\text { 6. AUTHOR(S) } \\
\text { Over, Ann, P.; Klem, Mark, K.; Motil, Susan, M. }\end{array}$}} & 5d. PROJECT NUMBER \\
\hline & & & & & 5e. TASK NUMBER \\
\hline & & & & & $\begin{array}{l}\text { 5f. WORK UNIT NUMBER } \\
\text { WBS } 825855.01 .03 .03\end{array}$ \\
\hline \multicolumn{5}{|c|}{$\begin{array}{l}\text { 7. PERFORMING ORGANIZATION NAME(S) AND ADDRESS(ES) } \\
\text { National Aeronautics and Space Administration } \\
\text { John H. Glenn Research Center at Lewis Field } \\
\text { Cleveland, Ohio 44135-3191 }\end{array}$} & $\begin{array}{l}\text { 8. PERFORMING ORGANIZATION } \\
\text { REPORT NUMBER } \\
\text { E- } 16228\end{array}$ \\
\hline \multirow{2}{*}{\multicolumn{5}{|c|}{$\begin{array}{l}\text { 9. SPONSORING/MONITORING AGENCY NAME(S) AND ADDRESS(ES) } \\
\text { National Aeronautics and Space Administration } \\
\text { Washington, DC 20546-0001 }\end{array}$}} & $\begin{array}{l}\text { 10. SPONSORING/MONITORS } \\
\text { ACRONYM(S) } \\
\text { NASA }\end{array}$ \\
\hline & & & & & $\begin{array}{l}\text { 11. SPONSORING/MONITORING } \\
\text { REPORT NUMBER } \\
\text { NASA/TM-2008-215045; AIAA-2007- } \\
6196\end{array}$ \\
\hline \multicolumn{6}{|c|}{$\begin{array}{l}\text { 12. DISTRIBUTION/AVAILABILITY STATEMENT } \\
\text { Unclassified-Unlimited } \\
\text { Subject Categories: } 16 \text { and } 18 \\
\text { Available electronically at http://gltrs.grc.nasa.gov } \\
\text { This publication is available from the NASA Center for AeroSpace Information, 301-621-0390 }\end{array}$} \\
\hline \multicolumn{6}{|c|}{ 13. SUPPLEMENTARY NOTES } \\
\hline \multicolumn{6}{|c|}{$\begin{array}{l}\text { 14. ABSTRACT } \\
\text { The NASA Vision for Space Exploration begins with a more reliable flight capability to the International Space Station and ends with } \\
\text { sending humans to Mars. An important "stepping stone" on the path to Mars encompasses human missions to the Moon. There is little doubt } \\
\text { throughout the stakeholder community that new technologies will be required to enable this Vision. However, there are many factors that } \\
\text { influence the ability to successfully infuse any technology including the technical risk, requirement and development schedule maturity, and } \\
\text { funds available. This paper focuses on effective infusion processes that have been used recently for the technologies in development for the } \\
\text { lunar exploration flight program, Constellation. Recent successes with Constellation customers are highlighted for the Exploration } \\
\text { Technology Development Program (ETDP) Projects managed by NASA Glenn Research Center (GRC). Following an overview of the } \\
\text { technical context of both the flight program and the technology capability mapping, the process is described for how to effectively build an } \\
\text { integrated technology infusion plan. The process starts with a sound risk development plan and is completed with an integrated project plan, } \\
\text { including content, schedule and cost. In reality, the available resources for this development are going to change over time, necessitating } \\
\text { some level of iteration in the planning. However, the driving process is based on the initial risk assessment, which changes only when the } \\
\text { overall architecture changes, enabling some level of stability in the process. }\end{array}$} \\
\hline \multicolumn{6}{|c|}{$\begin{array}{l}\text { 15. SUBJECT TERMS } \\
\text { Lunar; Exploration; Technology development; Propulsion; Energy storage }\end{array}$} \\
\hline \multicolumn{3}{|c|}{ 16. SECURITY CLASSIFICATION OF: } & $\begin{array}{l}\text { 17. LIMITATION OF } \\
\text { ABSTRACT }\end{array}$ & $\begin{array}{l}\text { 18. NUMBER } \\
\text { OF }\end{array}$ & $\begin{array}{l}\text { 19a. NAME OF RESPONSIBLE PERSON } \\
\text { STI Help Desk (email:help@sti.nasa.gov) }\end{array}$ \\
\hline $\begin{array}{l}\text { a. REPORT } \\
\text { U }\end{array}$ & $\begin{array}{l}\text { b. ABSTRACT } \\
\text { U }\end{array}$ & $\begin{array}{l}\text { c. THIS } \\
\text { PAGE } \\
\text { U }\end{array}$ & UU & $\begin{array}{l}\text { PAGES } \\
14\end{array}$ & $\begin{array}{l}\text { 19b. TELEPHONE NUMBER (include area code) } \\
\text { 301-621-0390 }\end{array}$ \\
\hline
\end{tabular}



